\title{
1. Introduction: From the legalistic to the effect-based approach in EU competition policy
}

\author{
Pier Luigi Parcu, Giorgio Monti and Marco \\ Botta
}

\section{THE ROLE OF ECONOMIC ANALYSIS IN EU COMPETITION POLICY: FROM THE 'LEGALISTIC' TO THE 'MORE ECONOMIC' APPROACH}

Since the Treaty of Rome was signed, the European Union has had a set of legal provisions to safeguard free competition within the internal market namely, Articles 101 and 102 of the Treaty on the Functioning of the European Union (TFEU). Nevertheless, for several decades, the European Commission and the Court of Justice of the European Union (ECJ) have shaped the enforcement of EU competition policy with limited reference to economic analysis, in terms of both theories of harm and methods of analysis.

A notorious example of this early enforcement approach is United Brands, a case in which both the Commission and the ECJ defined the relevant market on the basis of the product's features. According to the ECJ, a banana has 'certain characteristics ... which enable it to satisfy the constant needs of an important section of the population consisting of the very young, the old and the sick'. 'While the ECJ implemented a logic of 'demand substitution' to conclude that bananas represented a separate product market in comparison to other fresh fruit, it relied on the 'subjective' evidence (ie, product features), rather than on 'objective' evidence (ie, price trends).

Moreover, the Commission has seldom tried to assess the effects of market behaviour on competition dynamics, as well as possible justifications for the alleged anti-competitive behaviour. Once again, United Brands represents

1 Case C-27/76, United Brands Company and United Brands Continentaal BV $v$ Commission (1978) ECLI:EU:C:1978:22, para 31. 
a good example of this enforcement trend in the early years of EU competition law enforcement. In that decision, the Commission argued that the price of bananas imported by United Brands from Central America to the European Community was in breach of Article 102, since it was 'too high' and 'discriminatory'. ${ }^{2}$ As the main evidence of this abuse, the Commission showed that the price of bananas in Ireland was substantially lower than in continental Europe, even though the bananas were mostly unloaded in the port of Rotterdam and later transported to Dublin by road and ferry. ${ }^{3}$ In its decision, the Commission noticed that 'at its maximum price gap, Danish customers were paying 2738 times the price (of bananas) charged to Irish customers' ${ }^{4}$ However, according to the Commission, the price of bananas in Ireland should have been higher than in continental Europe, taking into consideration the higher transportation costs to the island and the fact that this price difference could not be explained either by differences in the applicable customs duties or in terms of product demand. ${ }^{5}$

In its ruling, the ECJ partially quashed the Commission's decision, concluding that the Commission had not taken into consideration alternative explanations to assess United Brands' pricing strategy. In particular, the Commission had failed to consider a number of internal documents which showed that the company was selling bananas in Ireland at loss. ${ }^{6}$ Moreover, contrary to the Commission's finding of price excessiveness, the price of bananas had not risen in the last 20 years 'in real terms' (ie, net of the inflation rate). ${ }^{7}$ Finally, the price difference with competitors was only 7 per cent - that is, a small difference 'which cannot automatically be regarded as excessive and consequently unfair' ${ }^{8}$ The Commission had, therefore, not provided sufficient economic evidence to satisfy the burden of proof of an unfair pricing case under Article 102 TFEU. The limits of the Commission's decision in United Brands is a good example of enforcement trends in the early years of EU competition policy: times when the quality of the Commission's analysis concerning the competition dynamics in the relevant market was still rather unsatisfactory.

Last but not least, the Commission and the ECJ often tried to frame competition policy as complementary to the free movement rules in the TFEU. In particular, the EU institutions generally followed a 'per se' approach vis-à-vis

2 Commission decision of 17 December 1975 relating to a procedure under Article 86 of the EEC Treaty (IV/26699 - Chiquita), OJ L-95/1, 09/04/1976.

$3 \quad$ Ibid, Section I.7, 'UBC's position in the Community'.

$4 \quad$ Ibid.

5 Ibid, Section II.b, 'Pricing Practice'.

6 Supra, Case C-27/76, para 261.

7 Ibid, para 265.

$8 \quad$ Ibid, para 266. 
market conducts that could restrict the free movement of goods and services within the EU internal market. A good example is Consten and Grundig: ${ }^{9}$ in this landmark ruling, the ECJ concluded that an exclusive distribution agreement between Grundig, a German manufacturer of electronic appliances, and Consten, a French distributor, was in breach of Article 101. The ECJ noted that the agreement 'tended to restore the national division in trade between the Member States' and thus should be assessed as an 'object' restriction under Article 101 TFEU; while it could not be justified under Article 101(3). ${ }^{10}$ However, the ECJ did not assess the effects of the agreement on consumer welfare. The parties argued that the ECJ should have examined whether there was sufficient inter-brand competition in the relevant market. They sought to convince the ECJ that the agreement was unlikely to result in higher consumer prices if there were significant rivals in the electronic appliances market in France. The ECJ disagreed and held that an agreement that restricted competition among wholesalers of the same product was contrary to the principle of free competition. ${ }^{11}$ It took a dim view of efforts by distributors to market goods which would result in their own product being 'individually distinct in the eyes of the consumer', leading to higher prices. ${ }^{12}$ The ECJ did not appear to consider the importance of marketing techniques as a means of competition and completely overlooked the risk that free riding poses to the interests of consumers in quality distribution. The per se approach found in Consten and Grundig is not an isolated case. In Hoffmann La Roche, for example, the ECJ concluded that fidelity rebates granted by the dominant firm were per se prohibited. ${ }^{13}$

To sum up, in its early years, EU competition policy was generally characterized by a lack of economics analysis. In other words, a form-based approach to EU competition policy enforcement prevailed. ${ }^{14}$ The Commission and ECJ mostly relied on qualitative rather than quantitative evidence; they did not assess the effects or possible justifications of the contested conduct.

Since the 1990s, however, the so-called 'more economic' approach has progressively replaced the legalistic approach in many aspects of EU competition policy. As noted by Bruzzone in this book, the more economic approach was

\footnotetext{
9 Case C-56/64, Établissements Consten SàRL and Grundig-Verkaufs-GmbH v Commission (1966) ECLI:EU:C:1966:41.

10 Ibid.

$11 \quad$ Ibid, $\mathrm{p} 342$.

$12 \quad$ Ibid, $\mathrm{p} 343$.

13 Case C-85//6, Hoffmann-La Roche \& Co AG v Commission (1979) ECLI:EU:C: 1979:36.

14 Among its major critics, see V Korah, 'EEC Competition Policy - Legal Form or Economic Efficiency’ (1986) 39 Current Legal Problems 85.
} 
first introduced by the Commission in relation to Article 101, in the context of the Vertical Block Exemption Regulation. ${ }^{15}$ The approach here was much more liberal than that found in earlier block exemptions: provided that the undertakings lacked market power and did not include certain types of 'hard-core' restrictions, their agreement was automatically exempted. Second, the Market Definition Notice in 1997 referred for the first time to the 'small but significant and non-transitory increase in price' (SSNIP) test to define the relevant market, rather than to the qualitative criteria mentioned by the ECJ in United Brands. ${ }^{16}$ Finally, with the adoption of the first Merger Control Regulation in $1989,{ }^{17}$ economic analysis unavoidably acquired growing importance in competition policy enforcement. In particular, the forward-looking nature of merger control and the need to minimize false negative errors required the Commission to upgrade the quality of its economic analysis in reviewing the notified concentrations. In relation to Article 102, on the other hand, the shift from the legalistic to the more economic approach began approximately one decade later in comparison to Article 101. In particular, only with the publication in 2009 of a Guidance Paper on Article $102^{18}$ did the Commission reveal its intention to accept an effect-based analysis in Article 102 and to consider possible efficiency justifications in assessing the alleged abusive conduct.

The approach followed by the EU Courts in relation to economic analysis in EU competition policy has been ambivalent. First, since its establishment in 1988, the General Court has closely reviewed the Commission's decisions, quashing a number of important rulings due to the lack of sufficient economic analysis of the anti-competitive effects of the contested conduct. As shown by the recent General Court ruling in $C K$ Telekoms,${ }^{19}$ this trend is particularly visible in the General Court rulings reviewing the Commission's negative decisions in the field of merger control. ${ }^{20}$ Second, in GlaxoSmithKline, the

15 Commission Regulation (EC) No 2790/1999 of 22 December 1999 on the application of Article 81(3) of the Treaty to categories of vertical agreements and concerted practices, OJ L-336/21, 29 December 1999.

16 Commission Notice on the definition of relevant market for the purposes of Community competition law, OJ C-372/5, 9 December 1997, paras 15-19.

17 Council Regulation (EEC) No 4064/89 of 21 December 1989 on the control of concentrations between undertakings, OJ L-395/1, 30/12/1989.

18 Communication from the Commission, Guidance on the Commission's enforcement priorities in applying Article 82 of the EC Treaty to abusive exclusionary conduct by dominant undertakings, OJ C-45/7, 24 February 2009.

19 Case T-399/16, CK Telecoms UK Investments Ltd v Commission (2020) ECLI: EU:T:2020:217.

20 See, in particular, the General Court rulings in GE-Honeywell and Tetra Laval. Case T-209/01, Honeywell International, Inc v Commission (2005) ECLI:EU:T:2005: 455; Case T-80/02, Tetra Laval v Commission (2002) ECLI:EU:T:2002:265. 
General Court first recognized that the objective of EU competition policy is to safeguard consumer welfare. ${ }^{21}$

By contrast, the ECJ has been more reluctant to modify its well-established case law. In particular, in a number of rulings, the ECJ pointed out that the objective of EU competition policy is to safeguard undistorted competition within the internal market, rather than consumer welfare. ${ }^{22}$ In addition, the ECJ pointed out in Post Danmark II that the Commission Guidance Paper on Article 102 was purely a soft law instrument, which - unlike ECJ case law was not binding on national competition authorities (NCAs). ${ }^{23}$

Nonetheless, in recent years the ECJ seems to have finally started a slow move towards a 'more economic' approach in competition policy enforcement. In Cartes Bancaires, the ECJ ruled that the Commission was not entitled to apply the notion of restriction by object to any agreement that restricted the economic freedom of one party, but only to those agreements where the welfare effects were clearly negative. For other agreements, the Commission was obliged to consider the economic effects. ${ }^{24}$ More recently, in Budapest Bank, the ECJ emphasized that the Commission and NCAs faced a high burden of proof to be able to assess an agreement as a restriction by object under Article 101.25 The NCAs should thus normally analyse the agreements under the 'effect category', assessing the competition dynamics in the market and possible justifications, rather than reverting to the 'shortcut' of the object restrictions. ${ }^{26}$ In relation to Article 102, the ECJ has accepted the possibility for the dominant firm to put forward some efficiency justifications (Post Danmark 1). ${ }^{27}$ Finally, in Intel, the ECJ emphasized that the goal of Article 102 is to safeguard consumers, rather than less efficient competitors ${ }^{28}-$ a shift in the goals

21 The goal of EU competition law is 'to prevent undertakings, by restricting competition between themselves or with third parties, from reducing the welfare of the final consumer of the products in question'. Case T-168/01, GlaxoSmithKline Services Unlimited v Commission (2006) ECLI:EU:T:2006:265, para 118.

22 In GlaxoSmithKline, the ECJ reversed the previous ruling of the General Court, pointing out that the EU competition rules safeguard 'not only the consumers, but also the structure of the market'. Case C-501/06, GlaxoSmithKline Services Unlimited v Commission (2009) ECLI:EU:C:2009:610, para 63.

23 Case C-23/14, Post Danmark A/S v Konkurrencerådet (2015) ECLI:EU:C:2015: 651 , para 52.

${ }_{24}$ Case C-67/13 P, Groupement des cartes bancaires (CB) v Commission (2014) ECLI:EU:C:2014:2204, paras 53-54.

25 Case C-228/18, Gazdasági Versenyhivatal v Budapest Bank Nyrt (2020) ECLI: EU:C:2020:265, paras 42-43.

26 Ibid, para 38.

27 Case C-209/10, Post Danmark A/S v Konkurrencerådet (2012) ECLI:EU:C: 2012:17, para 42.

28 Supra, Case C-413/14 P, para 133. 
of EU competition policy from internal market integration to the consumer welfare goal. The depth of these changes will be verified only with time.

\section{THIS BOOK}

This book discusses emerging trends in the role of economic analysis in EU competition policy. The ten contributions included in the present volume are authored by well-known lawyers and economists who have a strong academic background. Five main topics are discussed throughout the chapters of the book, as follows.

\subsection{Recent ECJ Jurisprudence}

In their chapters, Monti and Bruzzone discuss the recent rulings of the ECJ in Cartes Bancaires, Budapest Bank, Intel and Generics. ${ }^{29}$ As discussed above, in its latest rulings the ECJ has finally accepted the more economic approach in EU competition policy.

According to Monti, the recent ECJ rulings have brought EU competition policy closer to US antitrust law. First, the narrow interpretation of the category of object restrictions introduced by the ECJ in Budapest Bank resembles the approach followed by the US Supreme Court in the $1970 \mathrm{~s}:{ }^{30}$ in the aftermath of Sylvania, ${ }^{31}$ the US Supreme Court progressively broadened the categories of agreements that would be assessed under the 'rule of reason', while restricting the category of agreements that are per se prohibited. Second, Monti points out that the shift in the burden of proof introduced by the ECJ in Generics and Intel in relation to abuse of dominance cases is similar to the US 'quick look': the plaintiff can argue that an agreement is anti-competitive with an abbreviated economic assessment unless the defendant convinces the court that a 'deeper look' into the economics of the agreement is needed. In the latter case, the court will carry out a full analysis of the pro and anti-competitive effects of the agreement, on the basis of the evidence put forward by both parties. Third, in Cartes Bancaires, the ECJ's explanation of the sorts of conduct that fall to be prohibited as restrictions by object closely resembles that followed by the US courts to decide whether an agreement should be assessed as a per se restriction, rather than under the rule of reason. According to Monti, despite the dif-

\footnotetext{
29 Case C-307/18, Generics (UK) Ltd and Others $v$ Competition and Markets Authority (2020) ECLI:EU:C:2020:52.

30 Supra, Case C-228/18.

31 US Supreme Court, Continental TV, Inc v GTE Sylvania, Inc, 433 US 36, 59 (1977).
} 
ferences between the two legal orders, both systems have started to converge in the way that the burden of proof is allocated between plaintiff and defendant.

Bruzzone affirms that, even after the acceptance of the effect-based analysis by the ECJ, a number of questions remain open. First, the ECJ has never clarified whether anti-competitive conduct should be sanctioned under Articles 101-102 if it is 'likely' to harm the competitive process or simply 'capable' (ie, potentially) of doing so. Second, the increasing role of zero-price markets in the context of the digital economy calls for an assessment of the effects of the conduct on different parameters of competition, such as product quality and incentives to innovate. Third, in Intel, the ECJ accepted the logic of the 'as efficient competitor' (AEC) test, ${ }^{32}$ but it failed to explain under what circumstances (ie, what types of abuses) the test should be applied in practice. Finally, the ECJ should specify whether there is a de minimis rule in the application of Articles 101-102: the broad interpretation followed by the ECJ case law in relation to the concept of intra-community trade substantially limits the scope of application of national competition rules. According to Bruzzone, these are pending issues which will hopefully be clarified by the ECJ in its case law in the coming years.

\subsection{Market Definition}

In their chapters, Brennan and Robertson discuss the role of economic analysis in relation to the definition of the relevant market. Looking at the US experience, Brennan discusses the evolution of the economic tools used to define the relevant market. The author notices that the SSNIP test was first introduced in the 1982 US Horizontal Merger Guidelines, ${ }^{33}$ in order to provide legal certainty to the merging parties in relation to the approach followed by the US Department of Justice and the Federal Trade Commission to define the relevant market in reviewing a notified concentration. According to Brennan, the SSNIP test makes sense only in the context of merger review, since the hypothetical price increase at the basis of the SSNIP test can be determined 'before' and 'after' the merger. On the other hand, applying the SSNIP test in the context of ex-post antitrust investigations is particularly complex and highly speculative. In the context of merger review, market definition is essential to determine post-merger coordinated effects in oligopolistic markets. However, merger enforcement has mostly focused on unilateral conduct in the past two decades - that is, cases in which there is no real need of market

\footnotetext{
Supra, Case C-413/14 P, para 136.

33 www.justice.gov/archives/atr/1982-merger-guidelines (accessed on 18 February 2021).
} 
definition. Finally, it is worth noticing that new developments in merger simulation and econometrics have made market definition less relevant in recent years. In view of these considerations, according to Brennan, market definition has thus reached 'its peak' in antitrust enforcement and is now 'declining' in terms of relevance.

In her contribution, Robertson challenges Brennan's view concerning the declining relevance of market definition, arguing that 'market definition is central to any antitrust inquiry', in relation to both Articles 101-102 and merger control. However, Robertson recognizes that the peculiarities of the digital economy challenge the traditional approach in defining the relevant market in EU competition policy. First, the 'multi-sided' nature of digital markets and the 'envelopment strategies' carried out by digital conglomerate firms challenge the traditional narrow definition of relevant market, based on the idea of demand substitutability. Second, an open question is whether and to what extent activities relating to data harvesting may be considered as a separate relevant market. Finally, the traditional approach to market definition relies on prices (ie, static dimension of competition), while dynamic considerations - for instance, innovation - are often overlooked. Both in Dow/ Du Pont ${ }^{34}$ and in Bayer/Monsanto, ${ }^{35}$ the Commission introduced the concept of innovation spaces; the question is whether and to what extent the latter will be considered as separate relevant markets in the future.

The Commission is currently reviewing the 1997 Market Definition Notice; ${ }^{36}$ the new Notice should be published by 2022. According to Robertson, one of the main challenges for the new Notice is to shift the relevant market definition from being a preliminary step to define market power to become an aspect of market characterization - that is, defining the boundaries of competition law investigation and the appropriate theory of harm. The new Notice should also include references to multi-sided and zero-price markets, while complying with the ECJ case law. Finally, the Notice should recognize the new econometric methods that 'skip' the definition of the relevant market, while guaranteeing sufficient legal certainty to the firms that are subject to antitrust investigations.

34 Commission Decision of 27 March 2017 declaring a concentration compatible with the internal market and the functioning of the EEA Agreement (Case M.7932 Dow/DuPont), OJ C-353/9, 20 October 2017, Section 4.4.

35 Commission Decision of 21 March 2018 declaring a concentration to be compatible with the internal market and the EEA agreement (Case M.8084 - Bayer) Monsanto), OJ C-459/10, 20 December 2018, footnote 23.

$36 \mathrm{https}$ //ec.europa.eu/competition/consultations/2020_market_definition_notice/ index_en.html (accessed on 18 February 2021). 


\subsection{Competition Policy Enforcement in the Telecoms and Digital Markets}

In their chapter, Alimonti, Neurohr and Ralston discuss how economic analysis in EU competition policy should be adapted to the reality of the digital economy. The authors discuss the pro and anti-competitive effects of a number of practices carried out by digital platforms that are currently subject to antitrust scrutiny, such as personalized pricing by algorithms, most favoured nation clauses and self-preferencing and bundling by dominant digital platforms. According to the authors, every type of conduct has both pro and anti-competitive effects in the digital economy. Therefore, the authors call for an effect-based analysis in competition policy in the digital economy and a ban on any per se prohibition.

According to Alimonti, Neurohr and Ralston, competition agencies will face a number of challenges in carrying out an economic analysis of anti-competitive conduct in the context of the digital economy. On the one hand, it is becoming easier for NCAs to find quantitative data in digital markets, since the markets are more transparent. On the other hand, it is becoming more difficult for enforcement agencies to build solid theories of harm, taking into consideration the rapid evolution of these markets. Moreover, the Commission and the NCAs should employ a larger number of economists and data scientists in order to detect forms of tacit collusion implemented via algorithms. Such a change in the organizational structure of the NCAs is necessary since it is becoming more difficult to identify evidence of cartel formation. Finally, innovation considerations should be included in the competition analysis, at the level of both the definition of the relevant market, theories of harm and possible efficiency defences.

In his chapter, Crocioni discusses the economics of margin squeeze a type of abuse of dominance increasingly investigated in recent years, especially in the telecoms industry. The ECJ has recognized margin squeeze as a self-standing abuse of dominance under Article 102, independent from refusal to deal and predatory pricing. ${ }^{37} \mathrm{In}$ his chapter, Crocioni discusses, from an economic perspective, the conditions that a competition agency must fulfil in order to prove a case of margin squeeze successfully. First, the vertically integrated incumbent must be dominant in the upstream market; second, the upstream input must be 'indispensable' to produce the downstream service; third, the incumbent must have an 'incentive' to exclude the downstream competitor; fourth, a competitor 'as efficient as' the dominant firm must be unable 2011:83.

37 Case C-52/09, Konkurrensverket v TeliaSonera Sverige AB (2011) ECLI:EU:C: 
to operate in the downstream market, since its margins of profits would be excessively 'squeezed'; and finally, the conduct must have a potential negative effect on consumer welfare.

By reviewing a number of investigations on margin squeeze carried out by the European Commission and selected national competition authorities, Crocioni concludes that the conditions mentioned above are quite difficult to prove in practice, especially the AEC test. According to the author, it is essential for NCAs to verify the economic evidence concerning the margin squeeze with the incumbent's 'incentive' to exclude the downstream competitor. In other words, it is essential that NCAs verify the economic findings of margin squeeze with the qualitative evidence of the exclusionary strategy implemented by the vertically integrated firm.

\subsection{Damages Estimation in EU Competition Policy}

The trends discussed thus far mostly concern public enforcement of EU competition policy. However, the development of private enforcement of EU competition rules has also supported the specific development of economic analysis in this field. In order to estimate the damages suffered by the claimant, economists have elaborated a number of methods to develop the so-called 'counterfactual scenario' - that is, how the market would have developed in the absence of the competition law infringement. The damage is represented by the difference between the price observed in the 'real' world and the expected competitive price derived from the counterfactual scenario. Economists thus play an essential role in estimating the damages suffered by the defendant in the context of cases litigated in national civil courts concerning a breach of EU competition rules.

In their chapter, Maier-Rigaud and Heller discuss the main methods developed by economists to estimate the price overcharge in follow-on damage claims, as well as a number of additional aspects relevant in damages estimation, such as passing on, umbrella pricing, quantity effects and after-effects. In particular, the authors provide a new classification of the economics methods, in comparison to the classification provided in 2013 by the Commission Guidance Paper on damages estimation, ${ }^{38}$ based on their professional experience in damages estimation cases. According to the authors, there are only two methods to identify the counterfactual scenario: empirical comparison and simulation methods. The cost-price and financial methods are less useful,

38 Commission Staff Working Document, Practical Guide Quantifying Harm in Actions for Damages Based On Breaches of Article 101 or 102 of the Treaty on the Functioning of the European Union, Strasbourg, 11 June 2013. SWD(2013) 205. 
according to the authors, since they are based on heterogeneous categories of data. The selection of the method depends on the available data and the peculiarities of the market; the method should be selected by the economist free from any mindset and preconditions. While economists estimate the damage, judges must review the assumptions that underpin each counterfactual scenario model elaborated by the economists.

An important aspect in damages estimation is the degree of passing on of price increases caused by competition law infringements throughout the production chain. In other words, the question is whether and to what extent the direct customer of the infringer internalizes the price overcharge, rather than increasing the price of its products, by transferring the harm further downstream. In damage claims, passing on may have important consequences in terms of both damages estimation and legal standing. First, if the direct customer is the claimant, the competition law infringer can argue that the claimant partially or fully transferred the price overcharge downstream to its customers, and thus lost in part or completely a legal pretence of compensation (ie, passing on as a defence - the shield). Second, in the case of passing on, the indirect purchaser acquires legal standing as it has suffered economic harm (passing on as an offence - the sword). The principle of passing on has been both recognized by the ECJ in Manfredi $i^{39}$ and codified by the Damages Directive. ${ }^{40}$

In their chapter, Parcu and Rossi criticize the current legal framework concerning the principle of passing on as unbalanced and substantially detrimental to private enforcement of competition damages in Europe. In reality, passing on is mostly relied on in the courts as a 'defence' by the competition law infringer, rather than supporting the legal standing of indirect purchasers. According to the authors, the rebuttable presumption of passing on introduced by Article 14 of the Damages Directive may perversely encourage national judges to think that passing on 'is more probable than not'. Furthermore, given the lack of class actions in Europe, indirect customers rarely have incentives and access to sufficient evidence to start a damages competition action. As a consequence, Article 14 may actually only encourage the passing on defence, effectively demoting the search of damage claims by final consumers that have suffered competition violations. More precisely, since the passing on defence harms the direct purchaser's incentives to sue, the upstream cartelists

39 Case C-295/04, Vincenzo Manfredi v Lloyd Adriatico Assicurazioni SpA (2006) ECLI:EU:C:2006:461.

40 Directive 2014/104/EU of the European Parliament and of the Council of 26 November 2014 on certain rules governing actions for damages under national law for infringements of the competition law provisions of the Member States and of the European Union, OJ L-349/1, 5 December 2014. Arts 12-16. 
further benefit from the lack of countervailing buyer power from their direct customer. Finally, passing on rules discourage standalone damages claims: direct customers, which have better access to evidence in standalone cases, are less likely to sue, due to the risk of facing the passing on defence by the competition law infringer, which may result in them losing the case in court and incurring unexpected legal costs. In view of these considerations, Parcu and Rossi conclude that the current legal framework in Europe concerning passing on hampers, rather than encourages, private enforcement of competition rules in Europe.

\subsection{Assessment of Economics Evidence by National Courts}

The last two chapters included in this volume discuss the role of national administrative courts in reviewing the NCAs' decisions. In particular, the chapters discuss the challenges faced by national judges in assessing the economic evidence relied on by the competition agency in its decision. The two chapters take Italy and the Netherlands as case studies.

In her chapter, Judge Perna analyses the standard of judicial review followed by the Lazio Tribunale Ammministrativo Regionale and the Italian Consiglio di Stato in reviewing the legality of decisions of the Italian competition authority, the Autorità Garante per la Concorrenza ed il Mercato (AGCM). According to the author, the Italian administrative courts exercise a 'full' judicial review vis-à-vis AGCM decisions, in line with the Menarini case law of the European Court of Human Rights. ${ }^{41}$ In particular, following the examples of the ECJ, the Italian administrative courts not only check for possible breach of procedural rules by the AGCM, but also review the reliability of the economics evidence put forward by the authority in its decision. According to Perna, the main challenge faced by the judge is to apply 'vague' economics concepts (eg, dominant position, market power) to the specific facts of the case by assessing the arguments put forward by the agency and by the defendant.

In his chapter, Judge Albaers discusses the standard of judicial review followed by the College van Beroep voor het bedrijfsleven $(\mathrm{CBb})$ in reviewing the decisions adopted by the Dutch Competition Authority. The author offers a number of interesting conclusions, drawn from his experience as a judge at the $\mathrm{CBb}$. First, the author points out that a judge is expected to write a ruling, rather than an academic paper. In other words, the judge discusses the issue of the standard of proof only to the extent necessary to solve the facts of the case. Second, judges generally require a higher standard of proof in cases where

41 European Court of Human Rights, A Menarini Diagnostics Srl v Italy. Judgment ruled on 27 September 2011, N 43509/08. 
a sanction is imposed (eg, a fine). Nevertheless, no judge expects to be 100 per cent convinced by the arguments put forward by the authority; 50-70 per cent conviction is 'sufficient'. According to Albaers, economic evidence is treated by the reviewing court like any other evidence, but it is 'more complicated' to review, as the judge has to understand the technicalities of the market. Oral hearings are useful for the judge to ask questions. According to the author, economists hired by the parties should be supported by skilled lawyers who have mastered the specific area of law and who can translate the economic evidence into 'legalese'. Last but not least, Albaers points out that judges are never fully specialized in a narrow area of law, such as competition law. Therefore, every court panel should include both a specialized judge and new judges who can get acquainted with the legal field and the relevant case law.

The two chapters provide an interesting comparison of the challenges faced by the administrative judges of these Member States in reviewing the decisions of their competition authorities and especially the difficulties they face in absorbing the economic arguments. The similarity in the conclusions of the two chapters show that the identified trends represent useful lessons for the administrative courts of other EU Member States.

\section{CONCLUSIONS}

Over the past 60 years, the role of economic analysis in EU competition policy has substantially increased, in terms of the theories, methods and evidence relied on by the Commission and the NCAs during their investigations. In particular, during the last two decades, the 'more economic' approach has gradually replaced the initial 'legalistic' approach in EU competition policy enforcement.

Today, competition policy is one of the EU policy areas where lawyers and economists have complementary roles. With the possible exception of cartels, economists now take care of the substantive assessment of the majority of cases. On the other hand, lawyers play an important role in ensuring that the economists' assessment complies with the existing case law and legislation, as well as with the rules of enforcement and procedural guarantees.

As discussed in the previous pages, the advent of the digital economy, the growing role of private enforcement and the increasing number of decisions adopted by NCAs present major new challenges for the development of economic analysis of EU competition policy. Time will tell whether and to what extent the emerging trends identified in this book will further develop in the coming years. 